〈抄録〉第 22 回 日本臨床薬理学会年会 2001 年 12 月 $14 \sim 15$ 日 横浜

シンポジウム 3 : 臨床薬理学における Pharmacogenomics のインパクト

\title{
1.ファーマコゲノミクス分野における インフォマテイクス技術
}

北 島 正 人*

近年、臨床薬理学分野において、ゲノム情報 をもとに各個人に適した薬物療法（テーラーメ イド医療）の提供を目指すためのファーマコゲ ノミクスの概念が急速に拡大してきている。特 に、ファーマコゲノミクス分野の中で、薬物代 謝酵素であるチトクロームP 450 (P 450 ) の遺伝子多型による代謝能の差異は、個人ごと の血中薬物濃度を左右して薬効や副作用に影響 するため、テーラーメイド医療を実践する上で 重要な情報となってきている。さらに、医薬品 による薬物相互作用が、医薬品の安全性に重大 な障害をもたらす例も多数報告されているが、 その中で代謝酵素遺伝子欠損者に高頻度に発生 する事例も見出されており遺伝的多型と薬物相 互作用両面からの網羅的な情報提供が重要とな ってきている。

我々は、ファーマコゲノミクス分野における インフォマティクス技術として、P450の遺 伝的多型情報並びに薬物代謝機能情報を収集し たデータベースシステムを塩野義製薬株式会社 並びに 5 名のP 450 研究者（九州大学の大村 恒雄名誉教授、神戸大学の大川秀郎教授、北海 道大学の鎌滝哲也教授、武庫川女子大の吉田雄 三教授、産業技術総合研究所の後藤修主任研 究員) と共同開発したので御紹介する。

\footnotetext{
* 株式会社富士通九州システムエンジニアリング

干 814-8589 福岡市早良区百道浜 2-2-1
}

本データベースの内容は、P 450 遺伝子全 般の基本データベースと薬物代謝酵素（P 45 O ）の応用データベースの 2 つのパートに大別 される。(Fｉｇ．1)

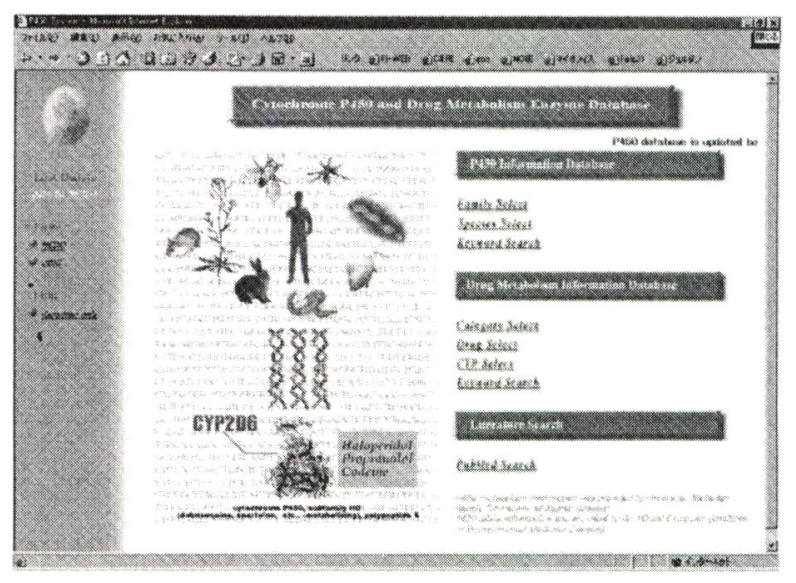

F i g . 1 データベースのトップ画面

[P450遺伝子全般の基本データベース]

基本データベースでは、既に配列が決定され ている生物の全ゲノム情報を用いて、そこに潜 んでいるP 450 遺伝子配列データを後藤先生 が開発した遺伝子発見プログラムを適用し、網 羅的に自動収集した。見つかったP 450 遺伝 子の機能アノテーション情報（配列情報、発現 情報、遺伝子マップ情報、文献情報等）を、外 部データベースから自動収集し、統合的なP 4 50 遺伝子データベースを構築した。これによ って，既存のデータベースを渡り歩く無駄と検 索漏れを省き、必要な情報に速やかに到達でき るようになった。 
[薬物代謝酵素(P 450 )の応用データベース]

応用データベースでは、薬物代謝酵素( P 45 O)の薬物代謝情報,発癌物質活性化情報、遺伝的 多型情報を文献ベースにより収集したものを独 自のデータベースに再構築した。これによって， 既存のデータベースを渡り歩く無駄と検索漏れ を省き，必要な情報に速やかに到達できるよう になった。データベースの項目数は、下記の通 りである。
·薬物代謝酵素（P450）

- 薬物

- 薬物代謝情報

-P450のSNPs 情報
54 種類

1, 557 種類

1, 512 種類

13 種類

\section{（1）薬物代謝情報}

応用データベースでは、薬物とそれを代謝す るP 450 の薬物代謝情報を提供する。薬物代 謝情報としては、各薬物が代謝される各P 45 ○の分子種とその反応様式、基質、阻害、誘導 等の反応タイプ及びその文献情報を閲覧できる。 文献情報は、P u b M e d とリンクしており、 文献のアブストラクトを表示することができる。 また、各文献には、記載されている薬物動態パ ラメータの項目を一覧表示しており、目的の文 献を簡単に探し出すことが可能である。

\section{（2）遺伝子多型情報}

応用データベースでは、また各P 450 遺伝 子の多型情報を収集して、データベース化して いる。各P 450 遺伝子におけるアレル情報、 変異情報活性情報等を一覧で表示している。各 アレルの変異部位は、遺伝子構造上の位置情報 をグラフィカルに表示できるようにしている。

また、共同開発者である塩野義製薬の馬場ら は、立体構造が判明している哺乳類のP 450

（CＹＰ２Ｃ５）を鋳型にして、薬物代謝酵素 の代表格であるCYP 2 D 6 をホモロジーモデ リングして、立体構造と遺伝子多型との関連性 について考察した。その結果、構造的に変化を うける遺伝子多型のほとんどが蛋白質表面に位
置していることが確認された。これは、P45 Oと基質や補酵素との相互作用になんらかの影 響があるものと思われる。

立体構造情報を含めた遺伝子多型情報を収集、 整理しておくことは、将来的に、各個人に合っ た薬の提供を行う「テーラーメード医療」実現 に向けての有用な情報となるものと期待される。

\section{具体的な使用例}

医療関係者にとって、処方する薬が、どのP 450 で代謝されるかを、本データベースを利 用することにより調べることが可能である。も し、処方する薬が、遺伝的多型の多いP 450 （例えば、CYP2D 6，CYP2 C 19 など） 1 種類しか代謝されない場合には、個人差による 副作用が発生することが考えられる。

また、薬物相互作用を回避するための薬を患 者に処方することは、副作用を起こさない為に も非常に重要なことである。薬物相互作用をお こす薬の飲み合わせに関しては、いろいろと報 告があるが、多剤併用が常套化しているうえ、 飲み合わせのバリエーションも多様化している ため、薬の併用による予期せぬ副作用に見舞わ れる可能性がある。

本データベースは、従来の各種データベース . サーフィンの弱点（労力，時間の浪費と検索漏 れ）を大幅に改善し、そのための基礎情報を効 率的に提供できるものと期待される。

おわりに

本データベースは、遺伝子研究，酵素化学研 究の基礎分野への対応のみならず、薬物代謝情 報をもカバーする多角的なデータベース構成で あるので、自然科学基礎分野から、医薬開発研 究、臨床現場まで活用されるものと期待される。 特に，遺伝的多型や薬物相互作用に関連して， 医薬品の適正使用にも活用できる可能性がある。 本データベースは、本年 4 月より、J B i C （バイオ産業情報化コンソーシアム）から、一 般公開を予定している。 